\title{
Graptolite-based evidence for a revised stratigraphic and structural setting of the Szechuan, Hunan and Xingchang antimony prospects, Exploits Subzone, central Newfoundland
}

\author{
S. Henry Williams ${ }^{1}$ and Peter Tallman 2 \\ IDepartment of Earth Sciences, Memorial University of Newfoundland, \\ St. John's, Newfoundland AIB 3X5, Canada \\ 2 Black Pine Limited, P.O. Box 216, Station C, St. John's, Newfoundland A1C 5J2, Canada
}

Date Received April 21, 1995

Date Accepted July 5, 1995

\begin{abstract}
Early Ordovician (late Arenig) graptolites are identified from strata near the Northwest Gander River of the Exploits Subzone which were previously considered to be of Silurian and/or middle Ordovician age. A second locality within a graphitic shale yields a Middle Ordovician (Caradoc) graptolite assemblage, suggesting that it is equivalent to the Lawrence Harbour Formation. The fossiliferous units are associated with antimony prospects and have fundamental implications regarding structural interpretation and age of mineralization. The early Ordovician occurrence is similar both in terms of age and biogeographic affinity to that from a fossiliferous greywacke unit which overlies ophiolites at Coy Pond to the south. This apparently confirms that early Ordovician rocks within the Exploits Subzone were formed in high latitudes along the southeast margin of Iapetus and suggests the possibility of widespread turbidite deposition at that time, possibly related to a major tectonic event.
\end{abstract}

On a repéré des graptolites de l'Ordovicien inférieur (Arénig tardif) dans des couches géologiques proches de la rivière Northwest Gander de la sous-zone d'Exploits, qui étaient auparavant considérées comme un secteur de la période du Silurien ou de l'Ordovicien moyen. Un deuxième emplacement à l'intérieur de schiste graphitique a donné une zone d'assemblage de graptolites de l'Ordovicien moyen (Caradoc), ce qui laisse supposer qu'elle équivaut à la Formation Lawrence Harbour. Les unités fossilifères sont associées à des zones d'intérêt d'antimoine et elles ont des répercussions fondamentales en ce qui touche l'interprétation structurale et l'âge de la minéralisation. La venue de l'Ordovicien inférieur est semblable, tant du point de vue de l'âge que de l'affinité biogéographique, à celle d'une unité de grauwacke fossilière qui recouvre des ophiolites à Coy Pond, au sud. Ce fait semble confirmer que les roches de l'Ordovicien inférieur à l'intérieur de la sous-zone d'Exploits ont été formées à de hautes latitudes le long de sud-ouest de la rive d'Iapetus et il permet de supposer la possibilité d'une sédimentation répandue de turbidite à cette époque, possiblement reliée à un événement tectonique marquant.

[Traduit par la rédaction]

\section{INTRODUCTION}

In 1989, Noranda Exploration discovered three antimony prospects in the Cooper Brook - Beaver Brook area near the Northwest Gander River, southwest of Gander Lake, while exploring for gold (Tallman, 1991). This "Hunan Line" area comprises Paleozoic lithologies belonging to the Exploits Subzone of the eastern Dunnage Zone (Williams, 1979; Williams et al., 1988) in apparent structural and/or intrusive contact with the southeast margin of the Silurian-Devonian Mount Peyton Intrusive Suite (Dickson, 1992).

Mapping at 1:250,000 scale by Anderson and Williams (1970) for the Geological Survey of Canada was the first regional survey of significance in the Hunan Line area, although a number of government, university, and industry studies between 1952 and the present have focused on the nearby Great Bend ophiolite complex (see Dickson, 1992). The Newfoundland Department of Mines and Energy (now Department of Natural Resources) has mapped various portions of the region at 1:50,000 scale since 1981 (Blackwood, 1981, 1982, 1983; Colman-Sadd and Russell, 1988; Dickson, 1992).

These previous workers have produced disparate interpretations of the regional geology, particularly regarding the age of the rocks and relationship to the intrusive suite. Anderson and Williams (1970) considered the strata to belong to the Silurian Botwood Group, based on lithological similarities to the type locality of that unit near Botwood. Blackwood (1981) subsequently discovered Middle Ordovician (Caradoc) graptolites from a graphitic shale horizon in Beaver Brook. He inferred the sequence at that locality to be an areally restricted thrust wedge of the Ordovician Davidsville Group surrounded by Botwood group strata. Dickson (1992) expanded the areal extent of Blackwood's Ordovician graphitic shale thrust wedge unit to the southwest, based on the presence of additional Caradoc-Ashgill graptolites. He furthermore interpreted the pebble greywacke hosting the Hunan antimony prospect to be another fault block containing Devonian or younger material, 
based on the observation of poorly developed bedding in limited surface exposures.

Graptolites discovered from Beaver Brook during the present study, which originate from Blackwood's (1981) locality, confirm the Caradoc age deduced by him and suggest a correlation with the widespread Lawrence Harbour Formation ("Caradoc black shale") which, together with its rich graptolite fauna, has been recorded from many parts of the Exploits Subzone (Williams, 1995). The discovery of graptolites from an apparently adjacent unit of ripple-marked siltstone in Cooper Brook, $1 \mathrm{~km}$ to the east-northeast (Fig. 1), unequivocally shows that unit to be early Ordovician (late Arenig) in age and not to belong to the Silurian Botwood Group. The recognition of these two distinct Ordovician ages sheds doubt on both previous and current stratigraphic and structural interpretations and has potential importance in constraining the timing of antimony mineralization in the region.

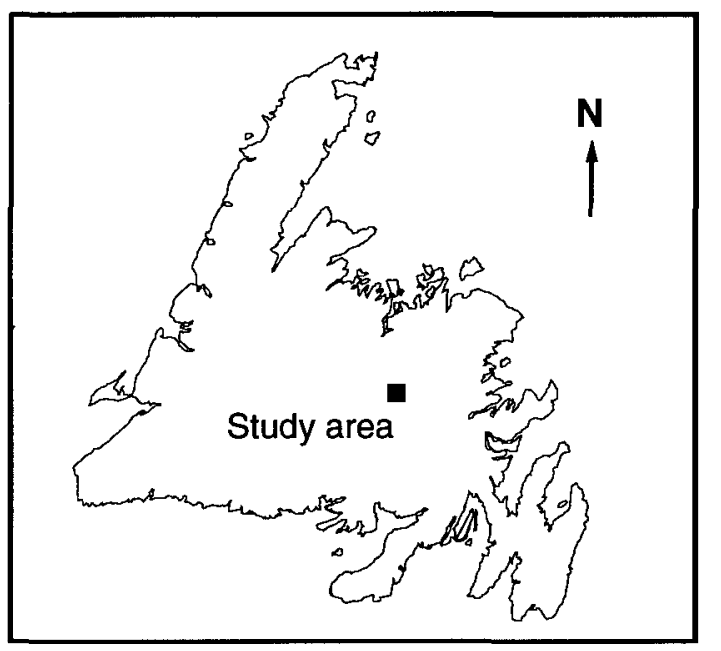

\section{Geological SeTting}

The Hunan Line area is composed of Paleozoic units belonging to the Exploits Subzone of the Dunnage Zone (Williams, 1979; Williams et al., 1988). Ordovician distal turbidites and Silurian epiclastic strata dominate. Sedimentary lithologies strike east-northeast-west-southwest, parallel to axial planes of local-scale open folds, and exhibit lower greenschist facies metamorphism. The contact between sedimentary lithologies and the Siluro-Devonian age Mount Peyton Intrusive Suite is well established (Anderson and Williams, 1970; Dickson, 1992). The Mount Peyton Intrusive Suite, a regional-scale polyphase batholith, comprises a variety of gabbro, granodiorite, tonalite and granite phases (Dickson, 1992).

The generalized stratigraphy of the Hunan Line area presented here is based on localized information gathered at the Szechuan, Hunan, and Xingchang antimony prospects and from
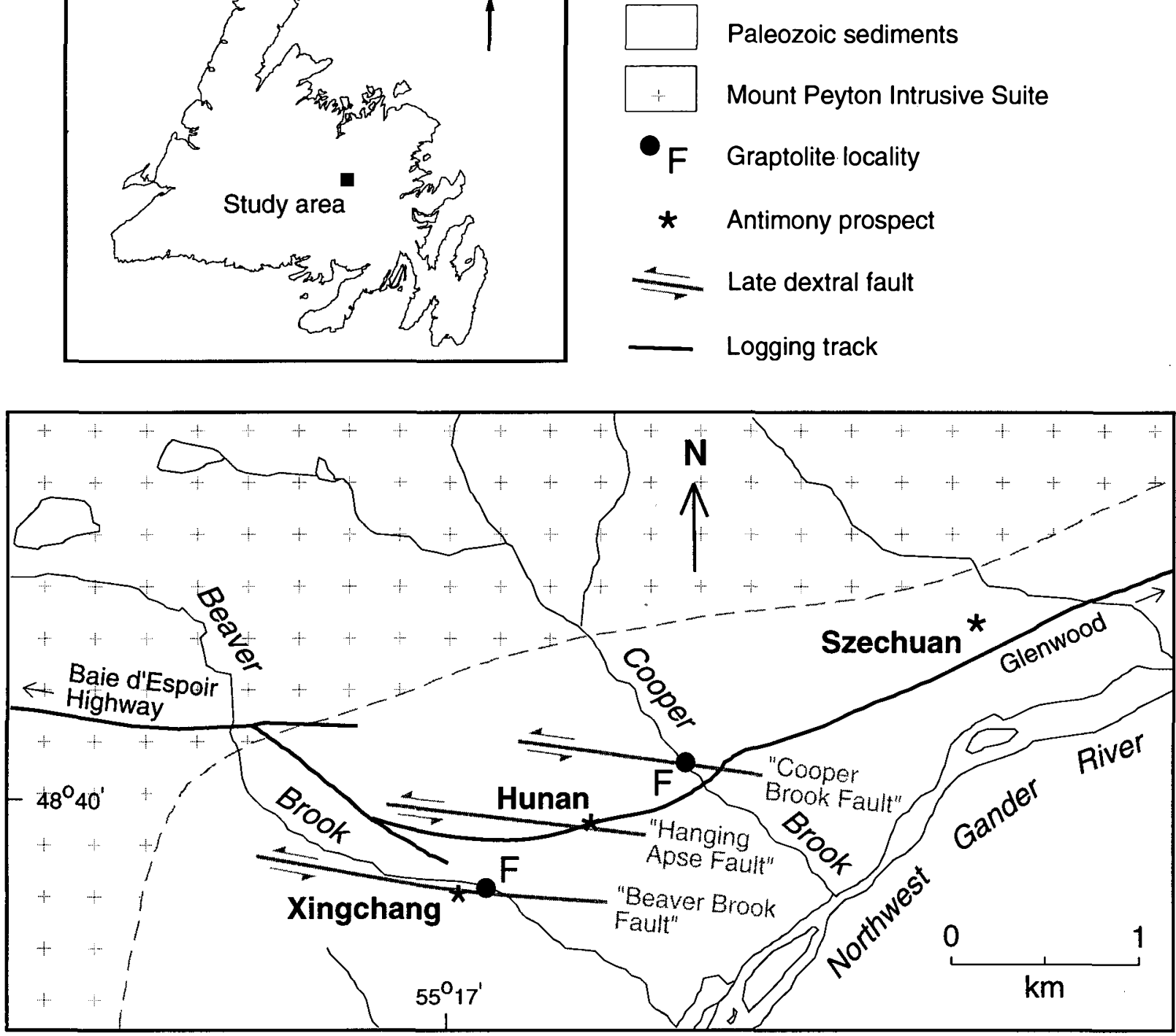

Fig. 1. Position of graptolite localities along the Hunan Line and relationship to geology and antimony prospects (modified from Tallman and Evans, 1994, fig. 2) 
mapped sections between them in Cooper Brook and Beaver Brook (Figs. 1, 2). The regional lithologic succession consists of a unit of rhythmically bedded siltstone underlying a distinctive pebble greywacke lithology, which in turn is overlain by a thick unit of black graphitic shale. No unequivocal "way-up" structures or biostratigraphic younging sequences have, however, been observed; it is therefore possible that the graptolitic graphitic shale is actually the oldest material present and is overlain by the pebble greywacke and siltstone units. Furthermore, the two graptolite assemblages of contrasting Arenig (at Cooper Brook) and Caradoc (at Beaver Brook) age, originally considered to have originated from the same unit, indicates that several graphitic shale intervals are actually present and at least partially invalidates previous map interpretations (e.g., Tallman and Evans, 1994).

Notwithstanding the above comments, we here refer to three informal divisions (Fig. 2). The rhythmically bedded siltstone member contains carbonate-rich grey-brown siltstones and silty sandstones which can exhibit reddish or purplish tinges from surficial weathering. Significant thicknesses of brown limestone occur which exhibit distinctive white (?)nodular structures in restricted horizons interlayered within the rhythmic siltstone sequence. Several graphitic black shale horizons, none in excess of $5 \mathrm{~m}$ thick, also occur within this stratigraphic unit.

The following pebble greywacke consists of a 30 to $90 \mathrm{~m}$ thick series of greywacke beds which range from granule to cobble in clast size and include quartz-poor/feldspar-rich and quartz-rich/feldspar-poor varieties. Individual beds range in thickness from 2 to $15 \mathrm{~m}$. Granule greywacke beds are massive and contain quartz and feldspar fragments as well as rare but slightly larger black shale clasts. Pebble greywacke is the most common unit. Both pebble and cobble greywacke horizons contain relatively more abundant black shale clasts, as well as a variety of sedimentary clasts. The unit exhibits a distinctive sericite- and chlorite-altered matrix.

The black graphitic shale unit consists of graphitic shale and dark grey siltstone which is commonly fractured, brecciated and faulted, but locally hosts a diverse, reasonably wellpreserved graptolite fauna. The siltstone units are rarely nongraphitic and generally finely laminated. The thickest section of this unit outcrops in Beaver Brook, where it is has an exposed horizontal thickness of $150 \mathrm{~m}$. The bimodal age distribution of graptolites, namely Caradoc and late Arenig, suggests that this unit either represents an extended interval of deposi-
No outcrop for $600 \mathrm{~m}$ to granite.

Rhythmically bedded siltstone and sandstone

Massive white sandstone

Reddish-grey siltstone, rhythmically bedded

Black graphitic shale breccia

Grey sittstone; local cobble beds

Purple and grey siltstone, mottled with "donuts"

Hunan pebble greywacke $(30 \mathrm{~m})$

Dark grey siltstone

Ripple-marked siltstone with abundant graptolites

Dark grey siltstone with $5 \mathrm{~m}$ graphitic black shale

Black graphitic shale breccia

Grey siltstone; local cobble beds

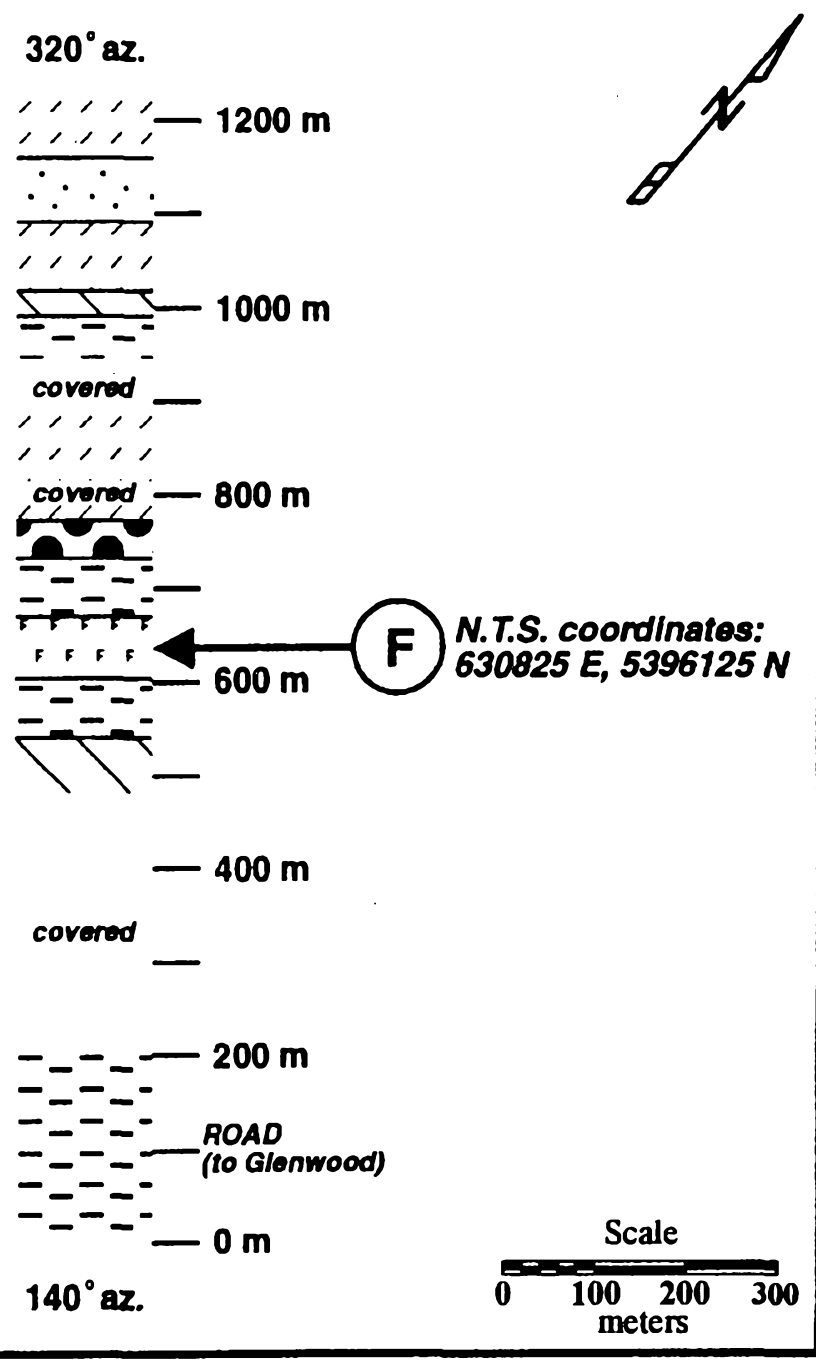

Fig. 2. Plan view along Cooper Brook, showing position of graptolitic interval and relationship to main lithological units. 
tion, or is a structurally composite sequence with a number of lithostratigraphically similar but discrete units which have been subsequently juxtaposed tectonically.

\section{REgiONAL STRUCTURE}

All Paleozoic strata appear to strike west-southwest/eastnortheast, and have generally been considered to young to the southeast. They exhibit a prominent bedding-parallel, $S_{1}$ cleavage. A considerable amount of deformation may have been accommodated as slip along these bedding/cleavage planes, particularly in siltstone and shale lithologies. The presence of lowangle bedding plane faults appears to be demonstrated by the two distinct graptolite assemblages in what was otherwise considered to be a single lithological unit (see above). $F_{2}$ fold axes are slightly inclined and steeply plunging to the northeast, and have locally produced an $S_{2}$ axial planar cleavage.

Fault breccias examined in drill core are oriented subparallel to the regional northeast-trending strike direction and locally can be found to transpose $F_{2}$ (?) fold hinges. Individual breccias range in width from $1 \mathrm{~cm}$ to $<10 \mathrm{~m}$ and are tentatively considered to be coeval with $F_{2}$ deformation.

Three late dextral faults, informally named "Cooper Brook fault", "Hanging Apse fault", and "Beaver Brook fault", are inferred from topographic lineaments, geophysical surveys and geological evidence to trend approximately $100^{\circ}$. These faults offset the regional stratigraphy by $50 \mathrm{~m}$ to $250 \mathrm{~m}$ and also truncate antimony-soil anomalies. Numerous $100^{\circ}$-trending brittle minor faults have 1 to $3 \mathrm{~m}$ offsets at the Hunan antimony prospect and control the disposition of stibnite veins.

Fault gouge zones observed in drill core locally transect fault breccias and appear to be the latest phase of deformation in the region. The orientation of fault gouge slip planes is not consistent but tends to be at a high angle to bedding and $S_{1}$ cleavage.

The Hunan Line area is approximately along structural strike from the Dog Bay Line in the northeastern Dunnage Zone (Williams et al., 1993). This major feature is marked by a zone displaying intense ductile deformation and imbrication of dark grey to black shales, volcanic rocks and gabbros followed by brittle deformation and dextral movement. It separates mostly terrestrial Silurian rocks in the west (Botwood Group) from equivalent mixed terrestrial and marine sequences in the eastern Exploits Subzone (Indian Islands Group), and is considered to possibly represent the terminal Iapetus suture (Williams et al., 1993). Although the Hunan Line area and Dog Bay Line exhibit broadly similar structural styles and stratigraphic relationships, they are geographically separated by over $70 \mathrm{~km}$. We therefore feel that additional evidence is needed before correlating between the two zones of deformation.

\section{Graptolte fauna from COOPER Brook}

\section{Taxonomic notes}

Graptolites were collected at UTM coordinates $630825 \mathrm{E}$, $5396125 \mathrm{~N}$. The assemblage is dominated numerically by diplograptids, with other taxa making up a minor constituent
(Fig. 3). The graptolites are suprisingly well preserved, lacking any obvious effects of tectonic strain; they are, however, difficult to observe owing to their reflectance levels and the rather pale, silty lithology which contains them. No preferred alignment appears to be present.

Aulograptus cf. cucullus (Bulman, 1932)

(Fig. 3a-d)

Some fifteen examples of a pendent, biramous rhabdosome include a complete proximal region. They are characterized by a slender but relatively long sicula 1.5 to $2.0 \mathrm{~mm}$ long and slender stipes which increase from $0.2 \mathrm{~mm}$ proximally to a maximum of $0.55 \mathrm{~mm}$. They generally exhibit no obvious thecal apertures; this is explained in a few specimens where the thecae can be seen to be "climacograptid" in style, with straight ventral walls subparallel to the dorsal margin and narrow, rounded apertures. This is in contrast with most pendent graptolites which possess typically "dichograptid" thecae with inclined ventral walls and simple apertures, and characterizes the genus Aulograptus Skevington, 1965.

Aulograptus was first described using material from the Llanvirn of Sweden; the only previous record from North America appears to be the " $A$. cf. cucullus" figured by Lenz and Jackson $(1986$, fig. $6 \mathrm{~h}$ ) from the upper part of the $P$. tentaculatus Zone of northwest Canada. Servais and Maletz (1992, p. 274) note that $A$. cucullus "is widely known around the Gondwanan margin"; with the one exception listed above, it has never been recorded from the Laurentian margin of Iapetus and thus appears to be typical of the higher latitude, periGondwanan/Avalonian and Baltic paleocontinents. Cooper et al. (1991, p. 206, fig. 3), however, record Aulograptus to be pandemic; as the source of their claim is not listed, it is unclear whether they are relying solely on the record of the genus from a low latitude region given by Lenz and Jackson (1986, see above). If so, we would consider the genus to be most characteristic of high latitude regions, but also with rare occurrences in lower latitude settings.

The material from Cooper Brook is insufficiently preserved to permit unequivocal identification to species level, but does appear to compare well with the descriptions of $A$. cucullus given by Bulman (1932), Skevington (1965), Rushton and Molyneux (1989) and Servais and Maletz (1992).

\section{Azygograptus? sp.}

(Fig. 3f)

Although a few stipe fragments which probably belong to this form are present in the sample, only one specimen with an apparently complete proximal region was recovered; it exhibits the inclined sicula with apertural modification, single stipe and simple, gently inclined thecae characteristic of Azygograptus. The thorough review and revision of the genus by Beckly and Maletz (1991) should permit critical comparison of the Newfoundland material with the previously described species. Unfortunately, however, their work clearly demonstrates the need for a number of specimens in order to make a specific determination; our material is thus inadequate for such a purpose. All examples of the genus and the similar Jishougraptus, which 


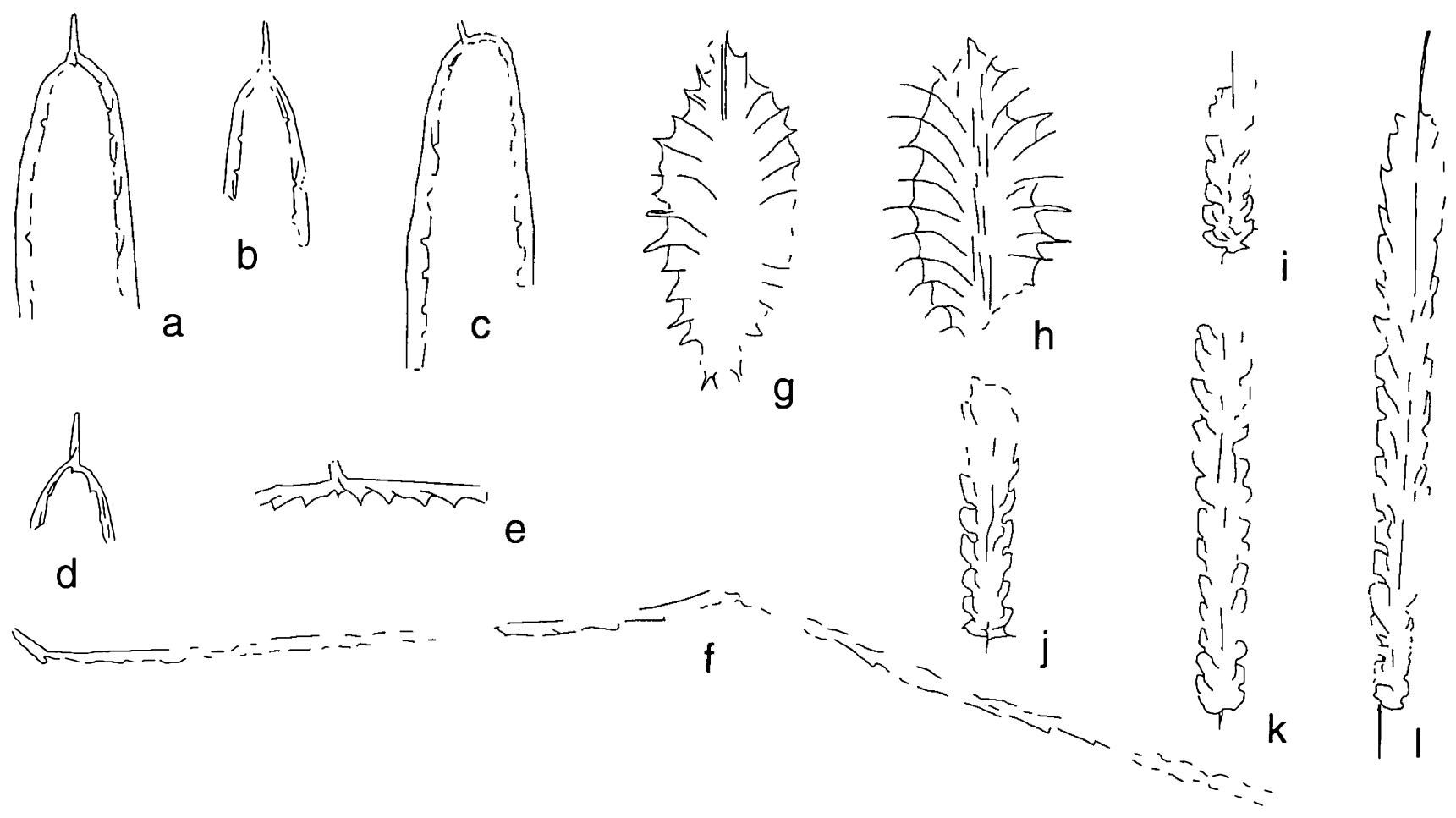

Fig. 3. Late Arenig graptolites from Cooper Brook (all x5). Housed in the collections of the Geological Survey of Canada, Ottawa. (a-d) Aulograptus cf. cucullus (Bulman). (a) GSC 113825. (b) GSC 113826. (c) GSC 113827. (d) GSC 113828. (e) Didymograptus (Expansograptus)? sp., GSC 113829. (f) Azygograptus? sp., GSC 113830. (g, h) Pseudophyllograptus? sp. (g) GSC 113831. (h) GSC 113832. (i-l) Undulograptus primus (Legg). (i) GSC 113833. (j) GSC 113834. (k) GSC 113835 . (l) GSC 113836.

posesses sinograptid thecae, that were discussed by Beckly and Maletz are early to middle Arenig in age (Lancefieldian 3 to Castlemainian 2 of the Australasian standard); our examples are thus younger than the species described by them, and may not be conspecific with any. True Azygograptus have previously been recorded only from northwest Europe and equivalent Gondwanan ("Atlantic province") regions and appear to be diagnostic of early Ordovician, high latitude regions (Cooper $e t$ al., 1991; Rigby and Rushton, 1991, p. 35). Unfortunately, the one reasonably good specimen recovered here is insufficient for definite identification of Azygograptus, but further collecting will perhaps produce unequivocal material.

\section{Didymograptus (Expansograptus)? sp.} (Fig. 3e)

Two extensiform rhabdosomes in the sample have a complete proximal region with visible sicula; they are, however, too poorly preserved to determine whether a virgella was present, meaning that their generic assignment to Didymograptus (Expansograptus) rather than Xiphograptus cannot be confirmed. The material is inadequate for any specific determination.

\section{Pseudophyllograptus? sp.}

(Fig. 3g, h)

Several examples of a quadriradiate graptolite are present, including one preserved in cross-section. They measure up to 5 $\mathrm{mm}$ wide and have a thecal density of 12 to $14 \mathrm{in} 10 \mathrm{~mm}$, but no complete proximal region is preserved, meaning that definite generic assignment (which is based on the presence or absence of a virgella; see Cooper and Fortey, 1982) is impossible.

\section{Undulograptus primus (Legg, 1976)}

(Figs. 3i-l)

Many hundreds of specimens of this diplograptid are present within the sample, but most are inadequately preserved to allow observation of proximal structure and thecal style. The rhabdosome has a Pattern B development (of Mitchell, 1987), increasing only gradually in width from $1.0 \mathrm{~mm}$ proximally to a distal maximum of $1.7 \mathrm{~mm}$. At least one proximal theca possesses a subapertural spine. Thecal density measures 14 in 10 $\mathrm{mm}$ proximally, decreasing distally to $10 \mathrm{in} 10 \mathrm{~mm}$. All thecae show pronounced sigmoidal curvature, but the median septum appears to be straight. This species appears to be identical with the material of $U$. primus described by Mitchell (1994) from the Cow Head Group of western Newfoundland and with that referred to $U$. cf. austrodentatus (Harris and Keble, 1932) by Williams et al. (1993) from the Coy Pond Complex to the south of the area discussed in the present paper. This suggests a stratigraphic link between the graptolitic units at Coy Pond and $\mathrm{CoO}-$ per Brook, and shows that both occurrences indicate a level equivalent to the $U$. austrodentatus Zone of western Newfoundland.

\section{Age and paleogeographic affinity}

The assemblage indicates a late Arenig or early Llanvirn age (depending on definition of the series boundary), equivalent to the $U$. austrodentatus Zone of western Newfoundland 
(Williams and Stevens, 1988). Although the assemblage includes some widely distributed taxa that occur in graptolitic sequences of similar age from elsewhere in North America (e.g., $U$. primus), the occurrence of $A$. cf. cucullus and possibly Azygograptus suggests an affinity with equivalent units in southern Scandinavia and Britain (e.g., Bulman, 1932; Skevington, 1965). The assemblage thus appears to lend some support to the conclusions published by Williams et al. (1993), who deduced that the early Ordovician (Arenig-Llanvirn) fauna of the Exploits Subzone is of Gondwanan affinity in contrast to the Laurentian forms of the later Ordovician (Caradoc-Ashgill). It also suggests that the sedimentary units of Cooper Brook are of similar or identical age to those overlying the Coy Pond ophiolite.

\section{AgE OF GRAPTOLITES FROM BEAVER BROOK}

Graptolites were collected at UTM coordinates 629600E, $5394100 \mathrm{~N}$. The fossiliferous black shales in Beaver Brook contain abundant but tectonically deformed graptolites including Pseudoclimacograptus scharenbergi (Lapworth), Climacograptus? brevis Elles and Wood and Corynoides calicularis Nicholson. This assemblage is indicative of a Middle Ordovician (Caradoc) age, probably being equivalent to the Climacograptus bicornis Zone of the widespread Lawrence Harbour Formation (Williams, 1995).

\section{Discussion}

Fossil evidence indicates that sediments hosting the Hunan and Xingchang prospects are part of a continuous early to mid Ordovician stratigraphic sequence which youngs to the southeast and belongs at least in part to the Davidsville Group or its equivalents. There is no evidence at present to suggest that this sequence is confined to a fault-bounded wedge as shown by Blackwood (1981) and adopted by Dickson (1992). Mapping in Beaver Brook suggests that the entire brook is underlain by a continuous sequence of Ordovician age lithologies which extends from the Mount Peyton Intrusive Suite to the Northwest Gander River. Micaceous sandstone found in the upper portion of Cooper Brook and west of the Szechuan prospect is "Botwood Group" in appearance, however, a similar unit of micaceous sandstone with abundant ripple marks exposed in Cooper Brook contains late Arenig graptolites.

One problem with the fossil ages obtained during this study is that they indicate that the local Hunan Line succession youngs to the southeast which apparently conflicts with regional stratigraphic relationships. Further work is required in the area between the Hunan prospect and the Northwest Gander River to document the lateral extent of Ordovician lithologies and determine if the Hunan Line stratigraphy is contiguous with Davidsville Group sedimentary rocks $15 \mathrm{~km}$ to the east.

The late Arenig graptolite assemblage is an Atlantic province fauna, indicating original formation of the rocks in a high latitude setting associated with the southeast margin of the Iapetus Ocean, and confirming conclusions made previously based on trilobites and graptolites from greywackes of similar age which overly ophiolitic material at Coy Pond to the south. The identical ages of both localities perhaps point to widespread turbidite deposition at that time, possibly related to a major tectonic episode within the area now comprising the Exploits Subzone.

\section{ACKNOWLEDGEMENTS}

Discovery of the fossiliferous material and study of the area occurred during work for Noranda Exploration and Roycefield Resources by P.T., and in conjunction with research funded by the Newfoundland Department of Natural Resources, Geological Survey Division and the Natural Sciences and Engineering Research Council of Canada (NSERC) through a grant to Mark Wilson (Memorial University of Newfoundland). S.H.W. also acknowledges financial support by NSERC. We thank Drs. A.C. Lenz, S. Rigby and J. Riva for their comments on an earlier version of the manuscript, and Dr. M.J. Melchin for his constructive review.

Anderson, F.D. and Williams, H. 1970. Gander Lake (west half), Newfoundland. Geological Survey of Canada, Map 1195A.

Beckly, A.J. and Maletz, J. 1991. The Ordovician graptolites Azygograptus and Jishougraptus in Scandinavia and Britain. Palaeontology, 34, pp. 887-925.

BlackwOod, R.F. 1981. West Gander River (2D/11 east half) and Dead Wolf Pond (2D/10 west half). Newfoundland Department of Mines and Energy, Map 81-100.

- - 1982. Geology of the Gander Lake (2D/15) and Gander River (2E/02) area. Newfoundland Department of Mines and Energy, Report 82-4, 56 p.

- 1983. Notes on the Geology of the Great Gull River map area (2D/06), Newfoundland. Newfoundland Department of Mines and Energy, Map 82-71.

Bulman, O.M.B. 1932. On the graptolites prepared by Holm: 4. new species of Didymograptus and Dicellograptus from Oland, with remarks on the development of Dicellograptus. Arkiv for Zoologi, 24A (9), pp. 15-21.

Colman-Sadd, S.P. and Russell, H.J. 1988. Miguels Lake (2D/ 12), Newfoundland. Newfoundland Department of Mines and Energy, Map 88-50.

Cooper, R.A. and Fortey, R.A. 1982. The Ordovician graptolites of Spitsbergen. Bulletin of the British Museum of Natural History, Geology, 36, pp. 157-302.

Cooper, R.A., Fortey, R.A., and Lindholm, K. 1991. Latitudinal and depth zonation of early Ordovician graptolites. Lethaia, 24, pp. 199-218.

Dickson, W.L. 1992. Ophiolites, sedimentary rocks, posttectonic intrusions and mineralization in the Eastern Pond (NTS 2D/ 11W) map area, central Newfoundland. Current Research, Newfoundland Department of Mines and Energy Report 92 1, pp. 97-118.

Harris, W.J. and Keble, R.A. 1932. Victorian graptolite zones and correlations and descriptions of their species. Proceedings of the Royal Society of Victoria, 44, pp. 25-48.

LEGG, D.P. 1976. Ordovician graptolites and trilobites from the Canning Basin, Western Australia. Geologica et Palaeontologica, 10 , pp. 1-58.

LenZ, A.C. and JACKson, D.E. 1986. Arenig and Llanvirn graptolite biostratigraphy, Canadian Cordillera. In Palaeoecology and biostratigraphy of graptolites. Edited by C.P. Hughes and R.B. Rickards. Geological Society, Special Publication 20 , pp. $27-45$.

Mitchell, C.E. 1987. Evolution and phylogenetic classification 
of the Diplograptacea. Palacontology (London), 30, pp. 143 195.

1994. Astogeny and rhabdosome architecture of the graptolites of Undulograptus austrodentatus species group. In Graptolite research today. Edited by Xu Chen, B.-D. Erdtmann and Yu-nan Ni. Nanjing University Press, China, pp. 4960.

RigBY, S. and Rushton, A.W.A. 1991. Where and when did they live? In Graptolites: writing in the rocks. Edited by W.D. Palmer and R.B. Rickards. Boydell Press, Woodbridge, United Kingdom, pp. 33-37.

Rushton, A.W.A. and Molyneux, S.C. 1989. The biostratigraphic age of the Ordovician Skiddaw Group in the Black Combe Inlier, English Lake District. Proceedings of the Yorkshire Geological Society, 47, pp. 267-276.

Servais, T. and Maletz, J. 1992. Lower Llanvirn (Ordovician) graptolites and acritarchs from the "Assise de Huy", Bande de Sambre-et-Meuse, Belgium. Annales de la Société Géologique de Belgique, 115, pp. 265-285.

Skevington, D. 1965. Graptolites from the Ontikan Limestones (Ordovician) of Olland, Sweden. II. Graptoloidea and Graptovermida. Geological Institutions of the University of Uppsala, Bulletin, 43, pp. 1-74.

Tallman, P. 1991. The 'Hunan Line' discoveries: antimony mineralization in central Newfoundland. In Ore Horizons. Volume 1. Edited by H.S. Swinden and A. Hogan. Newfoundland Department of Mines and Energy, Geological Survey Branch, pp. 11-21.
Tallman, P. and Evans, D.T.W. 1994. Geology of stibnite mineralization at the Hunan Line prospects, central Newfoundland. Current Research, Newfoundland Department of Mines and Energy, Report 94-1, pp. 263-271.

Williams, H. 1979. Appalachian Orogen in Canada. Canadian Journal of Earth Sciences, 16, pp. 792-807.

Williams, H., Colman-Sadd, S.P., and Swinden, H.S. 1988. Tectonic-stratigraphic subdivisions of central Newfoundland. Current Research, Part B, Geological Survey of Canada, Paper 88-1B, pp. 91-98.

Williams, H., Currie, K.L., and Piasecki, M.A.J. 1994 (for 1993). The Dog Bay Line: a major Silurian tectonic boundary in northeast Newfoundland. Canadian Journal of Earth Sciences, 30, pp. 2481-2494.

Williams, S.H. 1995. Middle Ordovician graptolites from the Lawrence Harbour Formation, central Newfoundland, Canada. Palacontographica, Abt. A, 235, pp. 21-77.

Williams, S.H. and Stevens, R.K. 1988. The Lower Ordovician (Arenig) graptolites of the Cow Head Group, western Newfoundland. Palaeontographica Canadiana, 5, $167 \mathrm{p}$.

Williams, S.H., Boyce, W.D., and Colman-Sadd, S.P. 1993 (for 1992). A new Lower Ordovician (Arenig) faunule from the Coy Pond Complex, central Newfoundland, and a refined understanding of the closure of the Iapetus Ocean. Canadian Journal of Earth Sciences, 29, pp. 2046-2057. 